\title{
Deskripsi Kemampuan Komunikasi Matematika dalam Menyelesaikan Soal Pemecahan Masalah Matematika Berdasarkan Gender
}

\author{
Muhammad Taqwa $^{1^{*}}$, Ahmad Budi Sutrisno \\ ${ }^{1,2}$ STKIP Andi Matappa, Pangkep, Sulawesi Selatan 90653, Indonesia
}

Pengiriman: 12 Juli 2019; Diterima: 23 Oktober 2019; Publikasi: 30 Oktoebr 2019

DOI: https://doi.org/10.31629/jg.v4i2.1336

\begin{abstract}
Abstrak
Penelitian ini merupakan penelitian kualitatif dengan tujuan (1) untuk mengetahui deskripsi kemampuan komunikasi matematika siswa laki-laki dan perempuan pada penyelesaian soal pemecahan masalah matematika, (2) untuk mengetahui informasi yang berbeda tentang deskripsi komunikasi matematika pada penyelesaian soal pemecahan masalah ditinjau dari gender. Subjek penelitian ini dua orang siswa kelas VII SMP Negeri 2 Labakkang yaitu satu orang siswa laki-laki dan satu orang siswa perempuan yang memiliki nilai tes pemecahan masalah tertinggi. Prosedur pengumpulan data dilakukan dengan observasi, pemberian tes pemecahan masalah dan wawancara. Instrumen penelitian digunakan berupa lembar observasi, tes pemecahan masalah, pedoman wawancara. Teknik analisis data dilakukan dengan melakukan uji kredibilitas, transferbility, dependability, serta conformability. Hasil penelitian menunjukkan bahwa kemampuan komunikasi matematika subjek gender laki-laki lebih rendah dari pada subjek gender perempuan. Letak perbedaan kemampuan komunikasi matematika antara gender laki-laki dan perempuan yaitu pada indikator menuliskan jawaban sesuai dengan maksud soal dan membuat kesimpulan secara tertulis menggunakan bahasa sendiri.
\end{abstract}

Kata kunci: komunikasi matematika; pemecahan masalah; gender

\begin{abstract}
This research is qualitative research with the aim of (1) to find out the description of mathematical communication skills of male and female students in solving mathematical problem solving questions, (2) to find out different information about mathematical communication descriptions in solving problem solving problems in terms of gender. The subjects of this study were two class VII students of SMP Negeri 2 Labakkang, namely one male and one female student who had the highest problem solving test scores. The procedure of data collection is done by observation, tests of problem solving and interviews. The research instrument was used in the form of observation sheets, tests of problem solving, interview guidelines. Data analysis techniques are carried out by testing credibility, transferbility, dependability, and conformability. The results showed that the mathematical communication skills of male gender subjects were lower than those of female gender subjects. The location of differences in mathematical communication skills between male and female gender is that the indicators write answers according to the purpose of the problem and make conclusions in writing using their own language.
\end{abstract}

Keywords: communication of mathematics; problem solving; gender

*Penulis Korespondensi

Email Address: muh.taqwa@stkip-andi-matappa.ac.id

Handphone : : +62 81242076641 


\section{JURNAL GANTANG. Oktober 2019; IV(2): 169 - 176 \\ p-ISSN. 2503-0671 \\ e-ISSN. 2548-5547}

\section{Pendahuluan}

Kemampuan komunikasi matematika menunjang kemampuan-kemampuan matematis yang lain, misalnya kemampuan pemecahan masalah. Masalah akan direpresentasikan dengan cepat dan benar jika kemampuan komunikasi baik serta mendukung untuk penyelesaian masalah. Untuk menyelesaikan masalah atau konsep matematika dengan baik, maka siswa harus memiliki kemampuan komunikasi matematis dengan baik.

Kemampuan komunikasi matematis didefenisikan suatu kemampuan siswa dalam mengutarakan pengetahuannya melalui peristiwa dialog atau saling hubungan yang terjadi dilingkungan kelas, dimana terjadi transfer informasi tentang materi matematika yang dipelajari siswa, misalnya berupa konsep, rumus, atau strategi penyelesaian suatu masalah (Nofrianto, Maryuni, \& Amri, 2017). Indikator komunikasi matematika adalah (1) Kemampuan menuliskan apa yang diketahui dan ditanyakan sesuai permasalahan; (2) Kemampuan menuliskan jawaban sesuai dengan maksud soal; (3) Kemampuan menuliskan alasan-alasan dalam menjawab soal; (4) Kemampuan menuliskan istilah-istilah dan simbol-simbol matematika; dan (5) Kemampuan membuat kesimpulan secara tertulis menggunakan bahasa sendiri. (Wijaya, Sujadi, \& Riyadi, 2016).

Namun, di tingkatan SMP atau SMA, komunikasi matematika belum berkembang. Rata-rata kemampuan komunikasi siswa berada pada kategori kurang khususnya aspek mengkomunikasikan ide-ide matematis sangat kurang sekali (Gantinah, 2014). Temuan lain, berdasarkan web Dinas Pendidikan Kabupaten Pangkajene dan Kepulauan, hasil ujian nasional di SMP Negeri 2 Labakkang mengalami penurunan selama 3 tahun, dimulai dari tahun 2015-2017. Dimana hasil ujian nasional pada tahun 2015 yaitu 72,34, pada tahun 2016 yaitu 56,64 dan pada tahun 2017 yaitu 34,05. Dan dari hasil observasi yang peneliti lakukan di SMP Negeri 2 Labakkang terhadap kelas $\mathrm{VIII}^{1}, \mathrm{VII}^{2}$ dan $\mathrm{VII}^{3}$. Pada hasil observasi yang dilakukan kelas VII1 memperoleh 88,23, kelas $\mathrm{VII}^{2}$ memperoleh 82,35 dan pada kelas $\mathrm{VII}^{3}$ memperoleh 70,58. Beberapa aspek yang dinilai dari hasil ujian nasional mengenai kemampuan pemecahan masalah, penalaran, komunikasi, pengetahuan tentang fakta, prosedur, penerapan pengetahuan, dan pemahaman konsep.

Terlihat bahwa rendahnya kemampuan komunikasi matematika siswa SMP Negeri 2 Labakkang. Kemampuan berpikir dan kemampuannya dalam berkomunikasi secara matematis seorang siswa menjadi faktor internal berhasilnya belajar matematika. Kemampuan memilih pendekatan yang sesuai materi dan konteks nyata siswa, menjadi salah satu faktor eksternal. Paradigma baru pendidikan lebih mengutamakan potensi utama dalam aktivitas siswa seperti kemampuan berpikir sementara guru berperan sebagai fasilitator yang membimbing siswa kearah pembentukan pengetahuan oleh diri mereka sendiri. Pemilihan pendekatan pembelajaran yang tepat oleh guru, dapat membangkitkan dan mendorong timbulnya aktivitas aktif siswa seperti kemampuan berpikir dalam pembelajaran yang pada akhirnya kemampuan komunikasi matematis siswa dapat meningkat (M. Ahmad \& Nasution, 2018)

Terlihat ada hubungan yang erat antara kemampuan komunikasi matematika dengan kemampuan pemecahan masalah. Aspek-aspek kemampuan pemecahan masalah dalam menyelesaikan soal matematika adalah pemahaman, penggunaan strategi dan prosedur matematis, dan komunikasi. Aspek komunikasi merujuk pada kemampuan memberikan penjelasan terhadap strategi, konsep-konsep terkait, dan prosedur matematis yang dilakukan; menggunakan representasi matematis, terminologi, dan notasi matematis; dan memaknai dan mengkomunikasikan solusi (Setiawati, 2014). Untuk menumbuhkembangkan kemampuan komunikasi matematika, maka perlu menyelesaikan masalah sebagai alat yang dapat mengkomunikasikan berbagai ide dengan ringkas dan jelas (clearly and succinctly) (Awaliyah, 2014). 
Pertanyaannya sekarang adalah bagaimana merancang soal pemecahan masalah yang dapat menumbuhkembangkan komunikasi matematika serta dapat diterapkan pada kelas yang heterogen, khususnya heterogen dalam jenis kelamin?

Perbedaan gender adalah perbedaan bawaan laki-laki dan perempuan yang dapat berubah setiap saat melalui upaya yang dilakukan. Perbedaan gender ini, menarik minat para ahli dalam melakukan penelitian. Khususnya penelitian yang terkait dengan komunikasi matematika. Hasil penelitian pada tingkatan SD sampai perguruan tinggi menunjukkan bahwa perbedaan gender dalam komunikasi matematika dan pemecahan masalah adalah area yang penuh dengan kontroversi. Menurut Murtafiah (2016) bahwa kemampuan komunikasi matematika mahasiswa perempuan baik secara tertulis maupun lisan dalam menyelesaikan masalah persamaan lebih baik jika dibandingkan dengan mahasiswa laki-laki, didukung pendapat Amir (2013) bahwa siswa perempuan lebih unggul dalam kemampuan komunikasi (verbal) matematika dibandingkan siswa laki-laki, sedangkan menurut Susilowati (2016), terdapat perbedaan kemampuan pemecahan masalah antara siswa laki-laki dan perempuan. Ternyata gender juga punya hubungan erat dengan komunikasi matematika dan pemecahan masalah.

Berdasarkan teori diatas, adapun rumusan masalah: (1) Bagaimana deskripsi kemampuan komunikasi matematika siswa laki-laki pada penyelesaian soal pemecahan masalah matematika? (2) Bagaimana deskripsi kemampuan komunikasi matematika siswa perempuan pada penyelesaian soal pemecahan masalah matematika? (3) Apakah ada informasi yang berbeda tentang deskripsi komunikasi matematika pada penyelesaian soal pemecahan masalah ditinjau dari gender? Tujuan penelitian: (1) Untuk mengetahui deskripsi kemampuan komunikasi matematika siswa laki-laki dan perempuan pada penyelesaian soal pemecahan masalah matematika; (2) Untuk mengetahui informasi yang berbeda tentang deskripsi komunikasi matematika pada penyelesaian soal pemecahan masalah ditinjau dari gender. Manfaat
Penelitian ini yaitu diharapkan dapat menambah wawasan serta pengalaman peneliti dalam melakukan penelitian serta dapat mengetahui bahwa perbedaan gender mempengaruhi kemampuan komunikasi siswa pada penyelesaian soal pemecahan masalah matematika.

\section{Metode Penelitian}

Penelitian dilakukan di SMP Negeri 2 Labakkang. Pendekatan yang digunakan dalam penelitian ini adalah kualitatif. Deskripsi fokus dalam penelitian ini adalah komunikasi matematika, dilihat dari cara dan bagaimana bahasa yang digunakan dalam menyampaikan pendapat. Subjek penelitian adalah siswa kelas VII. Pemilihan subjek penelitian berdasarkan teknik pengambilan purposive sampling.

Prosedur pengumpulan data meliputi: (1) Observasi yang dilakukan yakni untuk menentukan calon subjek penelitian; (2) Tes yang dilakukan yakni tes penyelesaian masalah yang bertujuan untuk mengambil 2 siswa untuk dijadikan subjek penelitian. Instrumen berupa tes uraian yang bertujuan untuk mengukur sejauh mana kemampuan komunikasi matematika yang dilihat dari jawaban peserta didik; (3) Wawancara yang dilakukan kepada 2 orang siswa terdiri dari 1 orang perempuan dan 1 orang laki-laki, untuk mengetahui komunikasi siswa terhadap penyelesaian masalah berdasarkan gender.

Instrumen penelitian meliputi: (1) Instrumen lembar observasi berupa aspek kemampuan komunikasi siswa yang akan dinilai; (2) Instrumen tes pemecahan masalah matematika yang berupa tes uraian ini bertujuan untuk mengetahui sejauh mana kemampuan komunikasi matematika tertulis peserta didik; (3) Instrumen instrumen pedoman wawancara diawali dengan mempelajari dan mengkaji kriteria kemampuan komunikasi matematika yang dijadikan pedoman dalam menyusun pertanyaan. Teknik analisis data dilakukan secara interaktif dan berlangsung secara terus menerus sampai tuntas, sehingga datanya sudah jenuh/konsisten. Proses analisis data dimulai sejak pengumpulan data sampai pada saat peneliti menyelesaikan tugas di lapangan. Pengecekan keabsahan data meliputi: (1) Uji kredibilitas data atau kepercayaan terhadap data 


\section{JURNAL GANTANG. Oktober 2019; IV(2): 169 - 176 \\ p-ISSN. 2503-0671 \\ e-ISSN. 2548-5547}

hasil penelitian dalam penelitian ini menggunakan teknik triangulasi; (2) Uji transferability dilakukan dengan memberikan uraian rinci, jelas, sistematis, dan dapat dipercaya dalam membuat laporan penelitiannya; (3) Uji dependability dilakukan dengan cara audit terhadap seluruh proses penelitian. Audit dalam penelitian ini akan dilakukan oleh kedua peneliti; (4) Uji confirmability merupakan pengujian hasil penelitian yang dilakukan oleh peneliti telah disepakati banyak orang. Dalam hal ini uji confirmability dilakukan bersama uji dependability oleh kedua peneliti.

\section{Hasil dan Pembahasan}

Peneliti melakukan observasi di kelas $\mathrm{VII}^{1}$, VII ${ }^{2}$, dan $\mathrm{VII}^{3}$. Dari observasi diperoleh kemampuan komunikasi matematika pada kelas VII $^{1}$ yaitu 88,23 , kelas VII $^{2}$ yaitu 82,35 dan kelas $\mathrm{VII}^{3}$ yaitu 70,58. Berdasarkan hasil tersebut kelas yang menjadi calon subjek peneliti adalah kelas VII $^{1}$.

Tabel 1.

Deskripsi kemampuan komunikasi matematika pada tes pemecahan masalah berdasarkan gender

\begin{tabular}{|c|c|c|c|}
\hline No & $\begin{array}{c}\text { Indikator } \\
\text { Kemampuan } \\
\text { Komunikasi } \\
\text { Matermaitika } \\
\end{array}$ & Subjek Laki-laki & Subjek Perempuan \\
\hline 1. & $\begin{array}{l}\text { Kemampuan } \\
\text { menuliskan apa yang } \\
\text { diketahui dan } \\
\text { ditanyakan sesuai } \\
\text { permasalahan }\end{array}$ & $\begin{array}{l}\text { - Pada soal nomor } 1 \text { penjelasan subjek } \\
\text { lebih sederhana dan subjek masih } \\
\text { merasa kesulitan untuk mencari } \\
\text { informasi yang diketahui dan yang } \\
\text { ditanyakan. } \\
\text { - Pada soal nomor } 2 \text { subjek tidak } \\
\text { merasa kesulitan dalam menuliskan } \\
\text { informasi yang diketahui dan yang } \\
\text { ditanyakan karena penjelasan subjek } \\
\text { lebih jelas pada wawancara. } \\
\text { - Pada soal nomor } 3 \text { penjelasan subjek } \\
\text { lebih lengkap. } \\
\text { - Pada soal nomor } 4 \text { penjelasan subjek } \\
\text { masing kurang lengkap misalnya } \\
\text { pada butir pertanyaan ke-1 yang } \\
\text { subjek ketahui adalah angka } \\
1,2,3,4,5,6,7,8,9 \text { dan operasi } \\
\text { hitung (+,-, } \times, \div) \text {. }\end{array}$ & $\begin{array}{l}\text { - Penjelasan subjek perempuan lebih jelas } \\
\text { dan subjek tidak merasa kesulitan dalam } \\
\text { mencari informasi yang diketahui dan yang } \\
\text { ditanyakan. } \\
\text { - Subjek perempuan juga tidak merasa } \\
\text { kesulitan dalam menuliskan informasi } \\
\text { diketahui dan ditanyakan tetapi penjelasan } \\
\text { subjek lebih sederhana pada soal nomor } 2 \text {. } \\
\text { - Subjek perempuan masih kurang lengkap. } \\
\text { - Subjek perempuan penjelasaanya lebih } \\
\text { lengkap misalnya pada butir pertanyaan } \\
\text { ke-1 yang subjek ketahui adalah } \\
\text { menggunakan tanda operasi hitung } \\
(+,-, \times, \div) \text { pada rangkaian angka } \\
1,2,3,4,5,6,7,8,9 \text { sehingga hasilnya } 100 \\
\text { tanpa merubah posisi angka tersebut. }\end{array}$ \\
\hline 2. & $\begin{array}{l}\text { Kemampuan } \\
\text { menuliskan jawaban } \\
\text { sesuai dengan maksud } \\
\text { soal }\end{array}$ & $\begin{array}{l}\text { - Pada soal nomor } 1 \text { penjelasan subjek } \\
\text { sudah tepat. Namun yang } \\
\text { membedakan dengan subjek } \\
\text { perempuan yaitu penyampaian } \\
\text { penjelasan tersebut. } \\
\text { - Pada soal nomor } 2 \text { penjelasan subjek } \\
\text { memiliki makna yang sama dengan } \\
\text { penjelasan subjek perempuan namun } \\
\text { yang membedakan ialah } \\
\text { penyampaian penjelasan tersebut. } \\
\text { - Pada soal nomor } 3 \text { subjek memiliki } \\
\text { jawaban yang kurang tepat dan } \\
\text { penjelasan subjek lebih sederhana. } \\
\text { - Pada soal nomor } 4 \text { penjelasan subjek } \\
\text { sudah tepat dan jelas. }\end{array}$ & $\begin{array}{l}\text { - Subjek perempuan juga memiliki } \\
\text { penjelasan yang sudah tepat. Namun yang } \\
\text { membedakan yaitu penyampaian } \\
\text { penjelasan tersebut. } \\
\text { - Penjelasan subjek perempuan memiliki } \\
\text { makna yang sama dengan penjelasan } \\
\text { subjek perempuan namun yang } \\
\text { membedakan ialah penyampaian } \\
\text { penjelasan tersebut. } \\
\text { - Subjek perempuan memiliki jawaban yang } \\
\text { kurang tepat tetapi pada penjelasannya } \\
\text { lebih jelas. } \\
\text { - Subjek perempuan penjelasannya sudah } \\
\text { tepat namun kurang jelas }\end{array}$ \\
\hline 3. & $\begin{array}{l}\text { Kemampuan } \\
\text { menuliskan alasan- } \\
\text { alasan dalam } \\
\text { menjawab soal }\end{array}$ & $\begin{array}{l}\text { Pada soal nomor 1, 2, } 3 \text { dan } 4 \text { subjek } \\
\text { selalu memberikan alasan pada setiap } \\
\text { langkah yang subjek buat karena agar } \\
\text { jelas dan mudah dimengerti. }\end{array}$ & $\begin{array}{l}\text { Subjek perempuan juga selalu memberikan } \\
\text { alasan pada setiap langkah yang subjek buat } \\
\text { karena untuk mendapatkan jawaban yang } \\
\text { benar. }\end{array}$ \\
\hline 4. & $\begin{array}{l}\text { Kemampuan } \\
\text { menuliskan istilah- }\end{array}$ & $\begin{array}{l}\text { - Pada soal nomor } 1 \text { dan } 2 \text { subjek tidak } \\
\text { merasa kesulitan untuk menuliskan } \\
\text { istilah dan simbol namun yang }\end{array}$ & $\begin{array}{l}\text { - Subjek perempuan juga tidak merasa } \\
\text { kesulitan untuk menuliskan istilah dan } \\
\text { simbol tetapi yang membedakan yaitu dari }\end{array}$ \\
\hline
\end{tabular}




\begin{tabular}{|c|c|c|c|}
\hline No & $\begin{array}{c}\text { Indikator } \\
\text { Kemampuan } \\
\text { Komunikasi } \\
\text { Matermaitika }\end{array}$ & Subjek Laki-laki & Subjek Perempuan \\
\hline & $\begin{array}{l}\text { istilah dan simbol- } \\
\text { simbol matematika }\end{array}$ & $\begin{array}{l}\text { membedakan dengan subjek } \\
\text { perempuan adalah penyampaian } \\
\text { penjelasan tersebut. } \\
\text { - Pada soal nomor } 3 \text { subjek tidak } \\
\text { merasa kesulitan untuk menuliskan } \\
\text { istilah dan simbol namun yang } \\
\text { membedakan adalah simbol yang } \\
\text { subjek sebutkan yaitu - dan =. } \\
\text { - Pada soal nomor } 4 \text { subjek tidak } \\
\text { merasa kesulitan untuk menuliskan } \\
\text { istilah dan simbol namun yang } \\
\text { membedakan dengan subjek } \\
\text { perempuan adalah penyampaian } \\
\text { penjelasan tersebut, dimana subjek } \\
\text { menjelaskan bahwa simbol } \times \text { untuk } \\
\text { mengalikan } 8 \text { dan } 9, \text { simbol + untuk } \\
\text { menjumlahkan } 1 \text { sampai } 7 \text { serta hasil } \\
\text { kali } 8 \text { dan } 9 \text { dan simbol = untuk } \\
\text { jawabannya. }\end{array}$ & $\begin{array}{l}\text { segi penyampaian penjelasan dalam } \\
\text { wawancara. } \\
\text { - Subjek perempuan juga tidak merasa } \\
\text { kesulitan untuk menuliskan istilah dan } \\
\text { simbol tetapi yang membedakan yaitu dari } \\
\text { segi simbol yang subjek sebutkan adalah + } \\
\text { dan }=\text {. } \\
\text { - Subjek perempuan juga tidak merasa } \\
\text { kesulitan untuk menuliskan istilah dan } \\
\text { simbol tetapi yang membedakan yaitu dari } \\
\text { segi penyampaian penjelasan tersebut, } \\
\text { dimana subjek menjelaskan simbol + untuk } \\
\text { menjumlahkan } 1 \text { sampai } 7, \text { simbol } \times \text { untuk } \\
\text { mengalikan } 8 \text { dan } 9 \text { dan simbol = untuk } \\
\text { hasil jawabnnya. }\end{array}$ \\
\hline 5. & $\begin{array}{l}\text { Kemampuan } \\
\text { membuat kesimpulan } \\
\text { secara tertulis } \\
\text { menggunakan bahasa } \\
\text { sendiri }\end{array}$ & $\begin{array}{l}\text { - Pada soal nomor } 2 \text { tidak memberi } \\
\text { kesimpulan karena subjek tidak dapat } \\
\text { menyelesaikan sampai akhir. } \\
\text { - Pada soal nomor } 3 \text { subjek telah } \\
\text { membuat kesimpulan meskipun } \\
\text { kurang tepat. } \\
\text { - Pada soal nomor } 4 \text { subjek tidak } \\
\text { memberikan suatu kesimpulan } \\
\text { dikarenakan waktunya tidak } \\
\text { mencukupi. }\end{array}$ & $\begin{array}{l}\text { - Subjek perempuan membuat suatu } \\
\text { kesimpulan walaupun pada penulisannya } \\
\text { terdapat kekeliruan. } \\
\text { - Subjek perempuan juga membuat } \\
\text { kesimpulan yang kurang tepat. } \\
\text { - Subjek perempuan juga tidak memberikan } \\
\text { kesimpulan karena waktunya tidak } \\
\text { mencukupi. }\end{array}$ \\
\hline
\end{tabular}

Kemampuan komunikasi yang pertama (1) yaitu kemampuan menuliskan apa yang diketahui dan yang ditanyakan sesuai permasalah, pada soal nomor 1 penjelasan subjek laki-laki lebih sederhana dan subjek masih merasa kesulitan untuk mencari informasi yang diketahui dan yang ditanyakan karena subjek sulit untuk mencari angka 1 sampai 6 untuk mengisi lingkaran tersebut. Sedangkan penjelasan subjek perempuan lebih jelas dan subjek tidak merasa kesulitan dalam mencari informasi yang diketahui dan yang ditanyakan karena sudah tertera jelas pada soal.

Pada soal nomor 2 subjek laki-laki tidak merasa kesulitan dalam menuliskan informasi yang diketahui dan yang ditanyakan karena penjelasan subjek lebih jelas pada wawancara. Dimana subjek menjelaskan bahwa yang diketahui dari soal yaitu bilangan cacah yang dibagi dua sama dengan 5 dan jumlah kedua bilangan cacah adalah 36. Sedangkan subjek perempuan juga tidak merasa kesulitan dalam menuliskan informasi diketahui dan ditanyakan tetapi penjelasannya lebih sederhana pada wawancara. Dimana subjek hanya mengatakan bahwa yang diketahu dan yang ditanyakan sudah jelas tertera pada soal.

Pada soal nomor 3 penjelasan subjek lakilaki lebih lengkap dari pada subjek perempuan. Dimana yang diketahui oleh subjek laki-laki yaitu tiga anak menebak 20, 23, dan 21, anak pertama tebakannya keliru satu angka, anak kedua keliru 3 angka dan anak ketuga penyelesainnya tepat. Sedangkan yang diketahui oleh subjek perempuan adalah tiga orang anak menebak banyaknya permen yang terdapat dalam plastik, anak pertama tebakannya keliru satu angka, anak kedua tebakannya keliru tiga angka dan anak ketiga penyelesainnya tepat.

Pada soal nomor 4 penjelasan subjek lakilaki masing kurang lengkap misalnya pada butir pertanyaan ke-1 yang subjek ketahui adalah angka $1,2,3,4,5,6,7,8,9$ dan operasi hitung $(+,-, \times, \div)$. Sedangkan subjek perempuan penjelasaanya lebih lengkap misalnya pada butir 


\section{JURNAL GANTANG. Oktober 2019; IV(2): 169 - 176 \\ p-ISSN. 2503-0671 \\ e-ISSN. 2548-5547}

pertanyaan ke-1 yang subjek ketahui adalah menggunakan tanda operasi hitung $(+,-, \times, \div)$ pada rangkaian angka $1,2,3,4,5,6,7,8,9$ sehingga hasilnya 100 tanpa merubah posisi angka tersebut.

Kemampuan komunikasi matematika yang kedua (2) yaitu kemampuan menuliskan jawaban sesuai dengan maksud soal, pada soal nomor 1 penjelasan subjek laki-laki dan perempuan sudah tepat, namun yang yaitu penyampaian penjelasan tersebut. Dimana subjek laki-laki menjawab soal dengan menjumlah angka 1 sampai 6 untuk mengisi lingkaran, sedangkan subjek perempuan menjawab soal dengan menggunakan angka 1 sampai 6 dan menjumlahkan sehingga berjumlah 9 .

Pada soal nomor 2 penjelasan subjek lakilaki dan perempuan memiliki makna yang sama namun yang membedakan ialah penyampaian penjelasan tersebut. Dimana subjek laki-laki menjelaskan bahwa cara subjek menjawab soal dengan memisalkan dengan huruf a dan $b$. Sedangkan subjek perempuan memisalkan bilangan tersebut dengan a dan $b$.

Pada soal nomor 3 subjek laki-laki dan perempuan memiliki jawaban yang kurang tepat tetapi penjelasan subjek laki-laki lebih sederhana dari pada subjek perempuan. Dimana cara subjek laki-laki menjawab soal dengan $20-1=$ $19,23-3=20$ dan $21=21$. Sedangkan cara subjek perempuan menjawab soal adalah karena anak pertama keliru satu angka jadi angka yang benar adalah 19 dan anak kedua keliru 3 angka jadi angka yang benar adalah 20 sedangkan anak ketiga penyelesainnya tepat yaitu angka 21 dan menjumlahkan ketiga angka tersebut yaitu $19+$ $20+21=60$.

Pada soal nomor 4 penjelasan subjek lakilaki sudah tepat dan jelas dimana penjelasan subjek adalah $1+2+3+4+5+6+7+8 \times$ $9=100$ sedangkan penjelasan subjek perempuan kurang jelas yaitu dengan menjumlahkan dan mengalikan angka tersebut.

Pada indikator kemampuan komunikasi matematika yang ketiga (3) yaitu kemampuan menuliskan alasan-alasan dalam menjawab soal, pada soal nomor 1, 2, 3 dan 4 subjek laki-laki selalu memberikan alasan pada setiap langkah yang subjek buat karena agar jelas dan mudah dimengerti. Sedangkan pada subjek perempuan juga selalu memberikan alasan pada setiap langkah yang subjek buat karena untuk mendapatkan jawaban yang benar.

Kemampuan komunikasi matematika yang keempat (4) yaitu kemampuan menuliskan istilah-istilah dan simbol-simbol matematika, pada soal nomor 1 subjek laki-laki dan perempuan tidak merasa kesulitan untuk menuliskan istilah dan simbol namun yang membedakan adalah penyampaian penjelasan tersebut. Dimana subjek laki-laki menjelaskan 6 lingkaran yang di isi dengan angka 1 sampai 6 agar setiap baris berjumlah 9 sedangkan subjek perempuan menjelaskan bahwa lingkaran yang menandakan baris dan jumlah angka dalam lingkaran sama dengan 9.

Pada soal nomor 2 penjelasan subjek lakilaki dan perempuan memiliki makna yang sama. Dimana kedua subjek memisalkan a dan b dua bilangan cacah. Pada soal nomor 3 subjek lakilaki tidak merasa kesulitan untuk menuliskan istilah dan simbol begitupula dengan subjek perempuan namun yang membedakan adalah simbol yang kedua subjek sebutkan. Dimana subjek laki-laki menyebutkan simbol - dan $=$ sedangkan subjek perempuan menyebutkan subjek + dan $=$.

Pada soal nomor 4 subjek laki-laki tidak merasa kesulitan untuk menuliskan istilah dan simbol begitupula dengan subjek perempuan. Namun yang membedakan subjek laki-laki dan perempuan adalah penyampaian penjelasan tersebut, dimana subjek laki-laki menjelaskan bahwa simbol $\times$ untuk mengalikan 8 dan 9 , simbol + untuk menjumlahkan 1 sampai 7 serta hasil kali 8 dan 9 dan simbol = untuk jawabannya sedangkan subjek perempuan menjelaskan simbol + untuk menjumlahkan 1 sampai 7 , simbol $\times$ untuk mengalikan 8 dan 9 dan simbol = untuk hasil jawabnnya.

Kemampuan komunikasi matematika yang kelima (5) yaitu kemampuan membuat 
kesimpulan secara tertulis menggunakan bahasa sendiri, pada soal nomor 2 subjek laki-laki tidak memberi kesimpulan karena subjek tidak dapat menyelesaikan sampai akhir. Subjek perempuan membuat suatu kesimpulan walaupun pada penulisannya terdapat kekeliruan. Pada soal nomor 3 subjek laki-laki dan perempuan telah membuat suatu kesimpulan meskipun kurang tepat. Kedua subjek menyimpulkan bahwa banyak permen adalah 60 serta kedua subjek membuat kesimpulan dengan melihat jawaban yang dikerjakannya. Pada soal nomor 4 subjek laki-laki dan perempuan tidak memberikan suatu kesimpulan dikarenakan waktunya tidak mencukupi.

Berdasarkan paparan diatas dapat dilihat bahwa kedua subjek memiliki perbedaan dalam kemampuan komunikasi matematika meskipun perbedaan tersebut tidak signifikan. Hal ini didukung oleh pendapat (Halpern, Diane, 2004); (Naftah, 2014), mengemukakan perbedaan gender yang reliabel berkaitan dengan kemampuan psikologis, khususnya dalam area-area yang menyangkut kemampuan berpikir, persepsi, dan memori. Perempuan unggul pada aspek kemampuan verbal, perbendaharaan kata, dan pengetahuan pada materi membaca dan menulis. Laki-laki ungul pada aspek kemampuan spasial, pengetahuan tentang geografi dan politik. Sejak sekolah tingkat umum (SMU), ada perbedaan kecil kemampuan matematika anak laki-laki dengan perempuan (Amir, 2013).

Komunikasi merupakan salah satu hal yang penting sehingga beberapa ahli melakukan riset tentang kemampuan komunikasi matematika (Ningsih, 2014). Beberapa hasil temuan dari penelitian (Fuentes, 1998); (Wahyuddin, 1999); (Osterholm, 2006); (A. Ahmad, Sitti, \& Rozianti, 2008); (Arwinie, 2014); (Wijaya et al., 2016), menunjukan bahwa aspek keterampilan dan ketelitian siswa dalam mencermati atau mengenali sebuah persoalan matematika masih rendah sehingga kemampuan komunikasi matematika siswa pun masih rendah.

Para peneliti saat ini menyadari bahwa faktor perbedaan gender merupakan hanya salah satu faktor yang mempengaruhi komunikasi matematika siswa, ada faktor lain, yaitu latar belakang sosial ekonomi. Lebih lanjut (Gross \& Thompson, 2007) menyimpulkan perbedaan gender dalam komunikasi matematika tergantung pada isi tugas, sifat pengetahuan dan keterampilan yang ditugaskan, serta kondisi saat mengerjakan tugas. Hal ini didukung hasil penelitian (Dewi, 2009) menyimpulkan bahwa komunikasi matematika mahasiswa perempuan lebih baik dibandingkan kelengkapan komunikasi matematika laki-laki, namun keakuratan komunikasi matematika mahasiswa laki-laki lebih baik dibandingkan dengan mahasiswa perempuan.

Untuk mahasiswa berkemampuan rendah dan sedang, komunikasi lisan (verbal) mahasiswa perempuan lebih baik dibanding mahasiswa lakilaki. Berdasarkan hasil-hasil penelitian di atas dapat disimpulkan bahwa perbedaan gender mempunyai andil untuk mendeskripsikan seseorang dalam menyelesaikan masalah dan mengomunikasikan hasilnya, namun perbedaan tersebut tidak signifikan.

\section{Kesimpulan}

Berdasarkan hasil tes pemecahan masalah terpilih dua subjek penelitian berdasarkan gender yaitu subjek laki-laki dan subjek perempuan. Hasil penelitian menunjukkan bahwa subjek laki-laki dan perempuan memiliki kemampuan komunikasi matematika yang berbeda. Letak perbedaanya ada pada indikator menuliskan jawaban sesuai dengan maksud soal dan membuat kesimpulan secara tertulis menggunakan bahasa sendiri. Pada indikator tersebut kemampuan komunikasi subjek perempuan lebih tinggi dari pada subjek laki-laki.

\section{Referensi}

Ahmad, A., Sitti, S. ., \& Rozianti, Z. (2008). A Cognitive tool to support mathematical communication in fraction word problem solving. Weseas Trasactions on Computer, 7, 228-236.

Ahmad, M., \& Nasution, D. P. (2018). Analisis kualitatif kemampuan komunikasi matematis siswa yang diberi pembelajaran matematika realistik. Jurnal Gantang, III(2), 83-95. https://doi.org/https://doi.org/10.31629/jg.v 3i2.471

Amir, Z. (2013). Perspektif gender dalam 
JURNAL GANTANG. Oktober 2019; IV(2): 169 - 176

p-ISSN. 2503-0671

e-ISSN. 2548-5547

pembelajaran matematika. Marwah, XII(1), $14-31$.

Arwinie, N. (2014). Meningkatkan kemampuan penalaran dan komunikasi matematis serta self concept MTS melalui pembelajaran berbasis masalah. (Unpulished Master Thesis). Sekolah Pascasarjana Universitas Pendidikan Indonesia.

Awaliyah, T. (2014). Pembelajaran untuk meningkatkan kemampuan komunikasi dan pemecahan masalah matematik. In Prosiding Volume 1 Seminar Nasional Pendidikan Matematika (pp. 180-187). Bandung: PPs STKIP Siliwangi.

Dewi, I. (2009). Profil komunikasi mahasiswa calon guru ditinjau dari perbedaan jenis kelamin. (Unpulished Doctoral Disertation ).PPS Universitas Negeri Surabaya.

Fuentes, P. (1998). Reading comprehension in mathematics. The Clearing House, 72(2), 81-88.

Gantinah, T. (2014). Meningkatkan kemampuan komunikasi dan koneksi matematis serta kemandirian belajar siswa sma melalui pembelajaran berbasis masalah. In Prosiding Volume 1 Seminar Nasional Pendidikan Matematika (pp. 408-418). Bandung: PPs STKIP Siliwangi.

Gross, J., \& Thompson, R. (2007). emotion regulation: conceptual foudation. (Handbook o). New York: Guilford Publication.

Halpern, Diane, F. (2004). A Cognitive - Process taxonomy for sex differences in cognitive abilities. Current Direction in Psycological Science, $\quad 22(1), \quad 68-72$. https://doi.org/10.1111/j.09637214.2004.00292.x

Murtafiah, W. (2016). Kemampuan komunikasi matematika mahasiswa calon guru matematika dalam menyelesaikan masalah persamaan diferensial ditinjau dari gender. Jurnal Math Educator Nusantara, 2(1), 3141.

Naftah, L. (2014). Pengaruh kemampuan spesial berdasarkan gender terhadap hasil belajar pada materi dimensi tiga siswa kelas $X$ di MAN Rojetongan. (Unpulished Master Thesis). Institut Agama Islam Negeri Tulungagung.

Ningsih, R. (2014). Efektifitas pendekatan kontekstual untuk peningkatan kemampuan komunikasi, pemecahan Masalah dan emandirian belajar siswa SMP. In Prosiding Volume 1 Seminar Nasional Pendidikan Matematika (pp. 320-324). Bandung: PPs STKIP Siliwangi.

Nofrianto, A., Maryuni, N., \& Amri, M. A. (2017). Komunikasi matematis siswa : pengaruh pendekatan matematika realistik. Jurnal Gantang, II(2), 113-122. https://doi.org/https://doi.org/10.31629/jg.v 2i 2.199

Osterholm, M. (2006). Metakognition and reading-criteria for comprehension of mathematics text. In Proceedings 30th Conference of International Group for the Psychology of Mathematics Education Vol. 4 (pp. 289-296). Prague: PME.

Setiawati, A. (2014). Meningkatkan kemampuan pemecahan masalah matematika siswa smp melalui pembelajaran kontekstual. In Prosiding Volume 1 Seminar Nasional Pendidikan Matematika (pp. 283-294). Bandung: PPS STKIP Siliwangi.

Susilowati, J. P. A. (2016). Profil penalaran siswa SMP dalam pemecahan masalah matematika ditinjau dari perbedaan gender. Jurnal Review Pembelajaran Matematika, 1(2), 132-148.

Wahyuddin. (1999). Kemampuan guru matematika, calon guru matematika, dan siswa dalam mata pelajaran matematika. (Unpulished Doctoral Disertation). Sekolah Pascasarjana Universitas Pendidikan Matematika.

Wijaya, H. P. I., Sujadi, I., \& Riyadi. (2016). Kemampuan komunikasi matematis siswa sesuai dengan gender dalam pemecahan masalah pada materi balok dan kubus (studi kasus pada siswa SMP kelas VIII SMP Islam Al Azhar 29 Semarang). Jurnal Elektronik Pembelajaran Matematika, 4(9), 778-788. 